\title{
DEPENDENCE OF INSULAR TOURISM ON ROAD AND LINER MARITIME PASSENGER TRAFFIC
}

\author{
VIDUCIC, $\mathrm{V}$.
}

Abstract: Croatia is a Central European, Danube-region and Mediterranean country. It is situated at the crossroads of Europe, Africa and Asia. Tourism has an important role in Croatian economy. Raising the service quality in tourism is the prerequisite for the repositioning of Croatian tourism and this is tightly associated with the traffic service quality. In this paper the subject of the research has been the dependence of insular tourism on road and liner maritime passenger traffic through the example of the island of Vis. Theoretical considerations on the impact of the transport on the tourism have been illustrated by the tourists' viewpoints, gathered through the field research, regarding the road and maritime infrastructure. As the result of the conducted research, recommendations have been made for the improvement of the road and maritime transport and for the necessary investments in accommodation facilities, which will increase the tourist service quality.

Key words: island tourism, road traffic, liner maritime passenger traffic
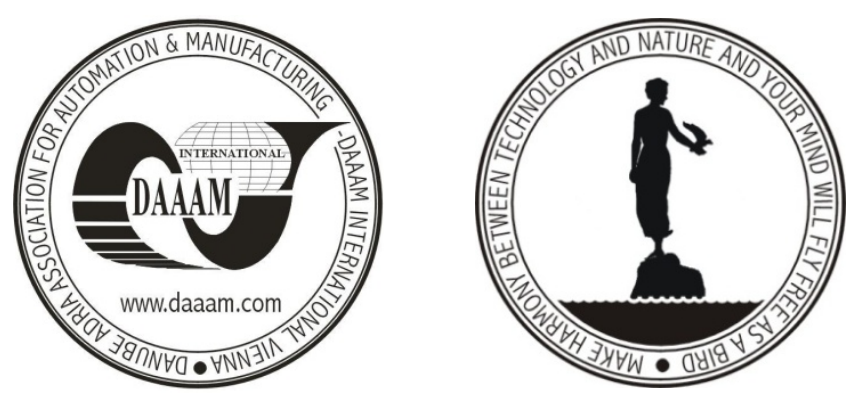

Authors' data: Dr. Viducic, V[inko], Maritime Faculty, Kneza Mislava 6,, 21 000, Podstrana, HR, vviducic@pfst.hr

This Publication has to be referred as: Viducic, V[inko] (2008). Dependence of Insular Tourism on Road and Liner Maritime Passenger Traffic, Chapter 77 in DAAAM International Scientific Book 2008, pp. 935-942, B. Katalinic (Ed.), Published by DAAAM International, ISBN 978-3-901509-66-7, ISSN 1726-9687, Vienna, Austria

DOI: $10.2507 /$ daaam.scibook.2008.77 